\title{
Effect of Farmyard Manure and Rate of Phosphatic Fertilizer on Phosphorus Availability and Yield of Corn
}

\author{
Hassanien, H.G. ${ }^{1}$; S.E. Abd El-mola ${ }^{2}$; A.A. Amin ${ }^{1}$ and H.K. El-Sayed ${ }^{2}$
}

${ }^{1}$ Department of Soils \& Water, Faculty of Agriculture, Assiut University, Assiut, Egypt

${ }^{2}$ Department of Soils \& Water, Faculty of Agriculture, AL-Azhar University, Assiut, Egypt

Received on: 15/11/2016

Accepted for publication on: 28/12/2016

\begin{abstract}
Farmyard manure (FYM) is a vital organic resource and their extensively used in soil management for sustainable agriculture. Field experiment was carried out during two successive growth seasons of 2014 and 2015 at the Experimental Farm of Department of Soils and Water, Faculty of Agricultural, ALAzhar University, Assiut governorate to examine the effect of farmyard manure and level of applied phosphatic fertilizeron phosphorus availability and corn (Zea mays) yield. The experiment was designed as a randomized complete block design in split plots with four replications. Results showed that the farmyard manure treatments ( 0 and $30 \mathrm{~m}^{3} /$ fed.) were assigned to the main plots and levels of superphosphate $(100,200$ and $300 \mathrm{~kg} / \mathrm{fed}$.) were in the sub-plots. The application of FYM to this soil increased significantly available phosphorus throughout two growth seasons. Also addition $30 \mathrm{~m}^{3} \mathrm{FYM}$ increased the grain yield of corn from 12.59 to $17.19 \mathrm{ardab} / \mathrm{fed}$. in first season and from 12.22 to $19.61 \mathrm{ardab} / \mathrm{fed}$ in the second season. Application of $30 \mathrm{~m}^{3}$ FYM combined with $200 \mathrm{~kg} / \mathrm{fed} \mathrm{su}-$ perphosphate resulted of increasing (GY) from 11.87 to $18.23 \mathrm{ardab} / \mathrm{fed}$. at first season and from 11.82 to $21.43 \mathrm{ardab} / \mathrm{fed}$. in second season. We Application of $200 \mathrm{~kg}$ superphosphate /fed combined with $30 \mathrm{~m}^{3}$ farmyard manure to the soil led to positive effect of this treatment on grain yield of corn.
\end{abstract}

Keywords: Farmyard manure, phosphorus, corn, grain yield.

\section{Introduction}

Phosphorus (P) is an essential macronutrient being required by plants in relatively large amounts. It primary role in plant is to store and transfer energy produced by photosynthesis for use in growth and reproductive processes. The availability of phosphorus in soils is affected by several factors such as soil $\mathrm{pH}$, clay and sesquioxide content, and exchangeable $\mathrm{Al}^{3+}$ (White, 2006), content and decomposition of organic matter in the soil and activities of microorganisms (Brady and Weil, 1999), soil water conditions and soil temperature (Sanchez, 2007). The application of farmyard manure to the soils led to improving soil chemical, physical and biologic properties (Belay et al., 2001). Soil pH values fell by one degree as result of adding farmyard manuredue to the decomposition and mineralization of organic matter (Singh et al., 1980). The available $\mathrm{P}$ in soils is increased significantly due to application of FYM (Ayuba et al., 2005; Adeniyan et al., 2011). The addition of organic manure to the soil increased Olsen-P because of the decreased $\mathrm{P}$ adsorption 
and phosphate potential (Bahl and Toor, 2002).

Corn is an important crop worldwide for food, animal feed and bioenergy production (Bello et al., 2010; Randjelovic et al., 2011). It is an important food crop in Africa. corn crop provides over $30 \%$ of the dietary calories in East Africa (Salasya et al., 1998). The yield of corn was improved with FYM application (Kihanda, 1996). Moreover, Zhao et al. (2009) found that the additions of FYM combined with chemical fertilizer caused enhanced of corn yield. The objectives of this study to examine the effects of farmyard manure and rate of phosphatic fertilizer on phosphorous availability and yield of corn.

\section{Materials and Methods Field experiment}

This study was carried out during two successive growth seasons of 2014 and 2015 at the agricultural Experimental Farm Department of Soils and Water, Faculty of Agricultural, AL-Azhar University, Assiut governorate to examine the effect of farmyard manure and phosphatic fertilizer on phosphorus availability and corn yield (Zea mays) yield. Some physical and chemical soil properties of the experimental soil and farmyard manure are given in Table (1). The experiment was designed as a randomized complete block in split plots with four replications. The farmyard manure treatments $\left(0\right.$ and $30 \mathrm{~m}^{3} / \mathrm{fed}$.) were assigned to the main plots and levels of super phosphate, $15.5 \%$ $\mathrm{P}_{2} \mathrm{O}_{5}(100,200$ and $300 \mathrm{~kg} /$ fed.) were in the sub-plots. The experimental unit area was $11 \mathrm{~m}^{2}(4 \times 2.8 \mathrm{~m})$ with three rows per plot was used. The ad- ditions of FYM and superphosphate fertilizer were done before planting. Corn grains were sown on May $5^{\text {th }}$ in the both growth seasons. Grains were sown in holes at space of $30 \mathrm{~cm}$ between each and $0.75 \mathrm{~m}$ between rows. Nitrogen and potassium fertilizers were added according to the recommendations of the Ministry of Agriculture. The nitrogen fertilizer was added to the soil at level $120 \mathrm{~kg} \mathrm{~N}$ /fed as Urea (46.5\%) and was applied in two doses. The potassium fertilizer was applied to the soil in one dose at $50 \mathrm{~kg} \mathrm{~K}_{2} \mathrm{SO}_{4}\left(50 \% \mathrm{k}_{2} \mathrm{O}\right)$. Corn plants were harvested after 110 days from planting and estimated biological yield per plot $(\mathrm{kg})$ as well as grain yield $(\mathrm{kg} / \mathrm{plot})$.Soil samples were taken from each plot after harvesting and prepared for analysis. Total P uptake by straw and grains was calculated using the following formulae:

$\mathrm{P}$ contents (\%) in plant part (dry matter) x Yield $(\mathrm{kg} / \mathrm{fed})$ Puptake $(\mathrm{kg} / \mathrm{fed})$ 100

Phosphorus use efficiency (PUE) on the basis of formulae as described by Fageria et al., (1997).

[Total P uptake $(\mathrm{kg} / \mathrm{fed})$ in fertilized plot]-[Total P uptake $(\mathrm{kg} / \mathrm{fed})$ in control plot] $\operatorname{PUE}(\%)=$

P dose applied $(\mathrm{kg} / \mathrm{fed})$

\section{Chemical analysis}

Available Phosphorus in soil was extracted by $0.5 \mathrm{M} \mathrm{NaHCO}_{3}$ at $\mathrm{pH} 8.5$ according to Olsen et al. (1954), and then it was determined calorimetrically using the chlorostanousphosphomolybdic acid method according to Jackson (1973). Available potassium was extracted using $1 \mathrm{M}$ ammonium acetate at $\mathrm{pH}$ 7 , and determined using the flame photometry method. Total nitrogen in soil was determined by micro- 
kjeldahl method (Jackson, 1973). The particle-size distribution analysis was conducted by pipette method and Organic matter was determined using the Walkley-Black method (Jackson, 1973). Soil pH measured in soil suspension by glass electrode. Electrical conductivity (EC) was measured in the soil extract using an electrical conductivity meter (Jackson, 1973). Calcium carbonate $\left(\mathrm{CaCO}_{3}\right)$ was estimated using a volumetric calcium carbonate calcimeter (Nelson, 1982). Phosphorous concentration in the digests was determined colorimetrically using the chlorostanousphosphomolybdic acid method according to Jackson (1973).

Table 1. Some physical and chemical analysis of the experimental soil and farmyard manure

\begin{tabular}{|c|c|c|}
\hline Property & \multicolumn{2}{|c|}{ Value } \\
\hline \multicolumn{3}{|c|}{ Particle size distribution } \\
\hline Sand $(\%)$ & \multicolumn{2}{|c|}{23} \\
\hline Silt (\%) & \multicolumn{2}{|c|}{34} \\
\hline Clay $(\%)$ & \multicolumn{2}{|c|}{43} \\
\hline Texture grade & \multicolumn{2}{|c|}{ Clay } \\
\hline Total-N (\%) & \multicolumn{2}{|c|}{0.12} \\
\hline Ava-P (mg kg $\left.{ }^{-1}\right)$ & \multicolumn{2}{|c|}{9.1} \\
\hline $\begin{array}{l}\mathrm{CH}_{3} \mathrm{COONH}_{4}-\mathrm{K}((\mathrm{mg} \\
\left.\left.\mathrm{kg}^{-1}\right)\right)\end{array}$ & \multicolumn{2}{|c|}{110.51} \\
\hline OM (\%) & \multicolumn{2}{|c|}{0.94} \\
\hline $\mathrm{EC}\left(\mathrm{dSm}^{-1}\right)_{(1: 2.5)}$ extract & \multicolumn{2}{|c|}{0.951} \\
\hline $\mathrm{pH}_{(1: 2.5)}$ suspension & \multicolumn{2}{|c|}{7.75} \\
\hline $\mathrm{CaCO}_{3}(\%)$ & \multicolumn{2}{|c|}{1.25} \\
\hline \multicolumn{3}{|c|}{ Farmyard Manure } \\
\hline & 2014 & 2015 \\
\hline $\mathrm{N}(\%)$ & 0.46 & 0.65 \\
\hline $\mathrm{P}(\%)$ & 0.3 & 0.18 \\
\hline $\mathrm{K}(\%)$ & 1.1 & 0.95 \\
\hline Organic matter $(\%)$ & 22.16 & 28.24 \\
\hline $\mathrm{C} / \mathrm{N}$ & 27.9 & 25.2 \\
\hline
\end{tabular}

\section{Statistical analyses}

Data obtained in this experiment were statistically analyzed by MSTAT program. Mean values were compared for each other using least significant difference (LSD) test at $P<0.05$ (MSTAT, 1987).

\section{Results and Discussion}

\section{Effects of Farmyard Manure \\ 1.1. Soil $\mathrm{pH}$ and Available Phosphorus}

The application of FYM to this soil decreased significantly soil $\mathrm{pH}$ during the two growth seasons (Tables 2). At first season, FYM added to the soil under study reduced soil $\mathrm{pH}$ from 7.67 to 7.57 , while, in the second season the decrease in soil $\mathrm{pH}$ from 7.68 to 7.54 . Many researchers found that the addition of FYM decreased soil pH (El-Ghamry et al., 2004; Shaikh and Gachande, 2013). Available phosphorus (Olsen-P) was significantlyincreased due to FYM application throughout the two growth seasons. The addition of FYM $\left(30 \mathrm{~m}^{3} /\right.$ fed.) enhanced Olsen-P from 9.44 to $16.3 \mathrm{mg} / \mathrm{kg}$ at first season and from 11.1 to $20.4 \mathrm{mg} / \mathrm{kg}$. This results similarly to (Singh et al.,1998). FYM additions in creased the availability of phosphorus in soil because the addition of P through FYM, and retardation of soil $\mathrm{P}$ fixation by organic anions formed during FYM decomposition (Ali et al., 2009). Increase in available phosphorus was due to the addition of phosphorus through manure fertilizer in excess of removal of crop (Muneshwar et al., 2008).

\subsection{Biological yield and Grain yield of corn}

Results of obtained showed that, the application of FYM caused significantly increase in biologicalyield (BY) and grain yield (GY) of maize during two growth seasons (Tables 2). Application of FYM to the soil under study led to an increase of (BY) from 9.94 to 11.68 ton/fed. and 
9.56 to 12.13 ton/fed at first and second seasons, respectively. Moreover, FYMadded to the soil raised the GY from 12.59 to $17.19 \mathrm{ardab} / \mathrm{fed}$. at first season as well as from 12.22 to 19.61 $\mathrm{ardab} / \mathrm{fed}$ in the second season.The application of FYM to soil signifi- cantly in creased the grain yield of maize plants according was also according by (Negassa et al., 2005). Increasing maize yields with increasing rates of farmyard manure was also according by (Kihanda, 1996).

Table 2. Effect of farmyard manure on Olsen-P, $\mathbf{p H}$, biological and grain yield of corn

\begin{tabular}{|c|c|c|c|c|c|c|c|c|}
\hline \multirow{2}{*}{$\begin{array}{c}\text { FYM treat- } \\
\text { ment }\end{array}$} & \multicolumn{4}{|c|}{ Season 2014 } & \multicolumn{4}{c|}{ Season 2015 } \\
\cline { 2 - 9 } & $\mathbf{p H}$ & $\begin{array}{c}\text { Olsen-P } \\
(\mathbf{m g} / \mathbf{k g})\end{array}$ & $\begin{array}{c}\mathbf{B Y} \\
(\mathbf{t o n} / \mathbf{f e d})\end{array}$ & $\begin{array}{c}\mathbf{G Y} \\
(\mathbf{a r d a b} / \mathbf{f e d})\end{array}$ & $\mathbf{p H}$ & $\begin{array}{c}\text { Olsen-P } \\
(\mathbf{m g} / \mathbf{k g})\end{array}$ & $\begin{array}{c}\mathbf{B Y} \\
(\mathbf{t o n} / \mathbf{f e d})\end{array}$ & $\begin{array}{c}\mathbf{G Y} \\
(\mathbf{a r d a b} / \mathbf{f e d})\end{array}$ \\
\hline without & 7.67 & 9.44 & 9.94 & 12.59 & 7.68 & 11.1 & 9.56 & 12.22 \\
\hline with 30m ${ }^{3}$ & 7.57 & 15.62 & 11.68 & 17.19 & 7.54 & 20 & 12.13 & 19.61 \\
\hline Fvalue & $*$ & $*$ & $*$ & $* *$ & $*$ & $*$ & $*$ & $* *$ \\
\hline
\end{tabular}

\subsection{Phosphorus concentra-} tions in shoot and grain of corn

The results showed a significant increase in $\mathrm{P}$ concentration in shoot of corn plant due to addition of farmyard manure in the first and second growth seasons (Table 3). Applying $30 \mathrm{~m}^{3} /$ fed. Farmyard manure increased $\mathrm{P}$ concentration in shoot of corn from 808.01 to 1177.28 in the first season and from 905.3 to 1076.9 ppm in the second season. The increase $\mathrm{P}$ concentration in plant shoots, because of the addition of organic manure in the soil was attributed to the increased in $\mathrm{P}$ availability (Mohanty et al., 2006). Significant increasesin $\mathrm{P}$ concentration (ppm) were observed in grain of corn plants duo to the additions of farmyard manure during to seasons. Adding FYM caused increase in $\mathrm{P}$ concentration (ppm) in grains of corn from 2560.8 to $2874.8 \mathrm{ppm}$ and 2492.7 to $2974.8 \mathrm{ppm}$ in the first and second seasons, respectively.

\subsection{Phosphorus Use Efficiency} and Phosphorus Uptake of Corn

Phosphorus use efficiency (PUE) and $\mathrm{P}$ uptake by corn plants weresignificantly increased withthe application of FYM to thesoil under study (Table 3). Application of FYM raised $\mathrm{P}$ uptake by corn plants from 9.02 to $15.39 \mathrm{~kg} /$ fed.andfrom 11.95 to $19.51 \mathrm{~kg} / \mathrm{fed}$. in first and second seasons, respectively. Application of FYM improved the phosphorus use efficiency ofcorn from 22.2 to $85.3 \%$ in first season and from 47.9 to $122.7 \%$ in the second season. Mohanty et al. (2006) found that the additions of FYM resulted in highest $\mathrm{P}$ use efficiency.

Table 3. Effect of farmyard manure on phosphorus content in shoot and grain as well as phosphorus uptake and use efficiency of corn

\begin{tabular}{|c|c|c|c|c|c|c|c|c|}
\hline \multirow[b]{2}{*}{$\begin{array}{c}\text { FYM } \\
\text { treatment }\end{array}$} & \multicolumn{4}{|c|}{ Season 2014} & \multicolumn{4}{|c|}{ Season 2015} \\
\hline & $\begin{array}{c}P \\
\text { concentratin in } \\
\text { shoot(ppm) }\end{array}$ & $\begin{array}{c}\mathbf{P} \\
\text { concentration } \\
\text { in grain(ppm }\end{array}$ & $\begin{array}{c}\text { P } \\
\text { uptake } \\
\text { (Kg/fed) }\end{array}$ & $\begin{array}{l}\text { PUE } \\
(\%)\end{array}$ & $\begin{array}{c}\mathbf{P} \\
\text { concentration } \\
\text { in } \operatorname{shoot}(\mathbf{p p m})\end{array}$ & $\begin{array}{c}\mathbf{P} \\
\text { concentration in } \\
\operatorname{grian}(\mathbf{p p m})\end{array}$ & $\begin{array}{c}\text { P } \\
\text { uptake } \\
\text { (Kg/fed) }\end{array}$ & $\begin{array}{c}\text { PUE } \\
(\%)\end{array}$ \\
\hline without & 808.01 & 2560.8 & 9.02 & 22.2 & 905.3 & 2492.7 & 11.95 & 47.9 \\
\hline With & 1177.28 & 2874.8 & 15.35 & 85.3 & 1077 & 2974.8 & 19.51 & 123 \\
\hline$F_{\text {value }}$ & * & $*$ & $* *$ & $* *$ & * & $*$ & $* *$ & $* *$ \\
\hline
\end{tabular}


2. Interaction between superphosphate and farmyard manure

\subsection{Available phosphorus}

Significant increases were observed the available phosphorus content in soil due the combined effect between superphosphate and farmyard manure applications (Table 4). The additions of superphosphate combined with farmyard manure led to enhancing the availability phosphorus from $7.68 \mathrm{mg} / \mathrm{kg}$ at $100 \mathrm{~kg}$ superphosphate without FYM treatment to 18.6 at $200 \mathrm{~kg}$ superphosphate with $30 \mathrm{~m}^{3}$ FYM treatment during first season, in the second season the available phosphorus was increased from 10.2 to $23.5 \mathrm{mg} / \mathrm{kg}$ at $100 \mathrm{~kg}$ superphosphate without FYM and 300 $\mathrm{kg}$ superphosphate with $30 \mathrm{~m}^{3}$ FYM treatments, respectively. (Tadesse et al., 2013) reported that the highest concentrations of available phosphorus after harvest was observed with the combined application of 6 ton/fed FYM with 20 and $40 \mathrm{~kg} / \mathrm{fedP}_{2} \mathrm{O}_{5}$.

Table 4. Grain yield and biological yield of corn as affected by farmyard manure and phosphatic fertilizer

\begin{tabular}{|c|c|c|c|c|c|c|c|c|c|}
\hline \multirow{2}{*}{ FYM Levels } & \multirow{2}{*}{$\begin{array}{c}\text { Superphosphate } \\
\text { Levels } \\
\left(\mathrm{P}_{2} \mathrm{O}_{5} \mathrm{~kg} / \mathrm{fed} \text {. }\right)\end{array}$} & \multicolumn{4}{|c|}{ Season 2014} & \multicolumn{4}{|c|}{ Season 2015} \\
\hline & & pH & $\begin{array}{l}\text { Olsen-P } \\
\text { (Mg/kg) }\end{array}$ & $\begin{array}{c}\text { BY } \\
\text { (ton/fed) }\end{array}$ & $\begin{array}{c}\text { GY } \\
\text { (arda/fed) }\end{array}$ & pH & $\begin{array}{l}\text { Olsen-P } \\
(\mathrm{mg} / \mathrm{kg})\end{array}$ & $\begin{array}{c}\text { BY } \\
\text { (ton/fed) }\end{array}$ & $\begin{array}{c}\text { GY } \\
\text { (arda/fed) }\end{array}$ \\
\hline \multirow{3}{*}{ Without } & 100 & 7.7 & 7.68 & 9.084 & 11.9 & 7.69 & 10.2 & 10.2 & 11.8 \\
\hline & 200 & 7.67 & 9.94 & 10.07 & 12.7 & 7.68 & 11.1 & 11.1 & 12.2 \\
\hline & 300 & 7.64 & 10.7 & 10.68 & 13.2 & 7.67 & 12.27 & 12.3 & 12.6 \\
\hline \multirow{3}{*}{ With } & 100 & 7.59 & 13.8 & 11.53 & 15.9 & 7.58 & 16.2 & 17.8 & 19 \\
\hline & 200 & 7.55 & 16.3 & 11.67 & 18.2 & 7.5 & 21.6 & 22.2 & 21.4 \\
\hline & 300 & 7.58 & 18.6 & 11.77 & 17.4 & 7.54 & 23.5 & 20 & 18.5 \\
\hline \multicolumn{2}{|c|}{$\mathrm{LSD}_{0.05}$} & NS & 0.98 & NS & NS & NS & 2.09 & NS & 0.29 \\
\hline
\end{tabular}

\subsection{Biological yield and Grain} yield of corn

Interaction between FYM and superphosphate levels is shown in Table (4). The application of FYM and phosphate fertilizer caused significant increase in BY and GY during two growth seasons. The combined application at $300 \mathrm{~kg}$ superphosphate /fed resulted in improved of BY from 9.084 to 11.77 ton/fed at first season while, the addition of $30 \mathrm{~m}^{3}$ FYM and superphosphate at level $200 \mathrm{~kg}$ increase the By from 10.2 to 22.2 ton/fed. The grain yield was increased from 11.9 to 18.2ardab/fed. at the first season due the addition FYM combined $200 \mathrm{~kg}$ superphosphate/fedat first season. Moreover, the addition of FYM and $200 \mathrm{~kg}$ superphosphate cased in- creased GY from 11.8 to 21.4 at the second season. Zhang et al. (2009) reported that application of pig manure and $\mathrm{P}$ fertilizers significantly enhanced grain yields of corn. Many workers found that the farmyard manure combined with chemical fertilizer led to increaseof corn yield (Fan et al., 2008; Zhao et al., 2009).

\subsection{Phosphorus concentration} in shoot and grain of corn

The concentration of phosphorus in shoot and grain of cornplants were in creased significantly due the additions of FYM with super phosphate (Table 5). Throughout the first season, $\mathrm{P}$ concentration in shoot was increased from 718.1 to $1308 \mathrm{ppm}$ at due addition $100 \mathrm{~kg}$ superphosphate without FYM. $300 \mathrm{~kg}$ superphosphate with $30 \mathrm{~m}^{3}$ FYM increased from 850 
to $1195 \mathrm{ppm}$ at same treatments during second season. The content of phosphorus in corn grains was significant increased with additions of FYM with superphosphate during the two growth seasons. The highest values of phosphorus concentration in grain are observed due to the addition of $200 \mathrm{~kg}$ super phosphate with FYM in two seasons.

\subsection{Phosphorus use efficiency} and phosphorus uptake of corn

The additions of FYM and superphosphate to the soil under study caused non significant increase of the total phosphorus uptake by corn. The phosphorus use efficiency (PUE) was increased significantly due to combined effect of FYM and superphosphate fertilizer in the second season, while at the first season this effect was non significant on (PUE) (Table 5). The combined application at $100 \mathrm{~kg}$ superphosphate with $30 \mathrm{~m}^{3}$ FYM resulted in increasing PUE from 132.1 and $213.9 \%$ at first and second season, respectively. The applications of phosphate fertilizers and farmyard manure led to improve nutrient $\mathrm{P}$ use efficiency (Adembaa et al., 2015).

Table 5. Effect of interaction between farmyard manure and superphosphate on phosphorus concentration in shoot and grain as well as $\mathbf{P}$ uptake and phosphorus use efficiency of corn

\begin{tabular}{|c|c|c|c|c|c|c|c|c|c|}
\hline \multirow[b]{2}{*}{$\begin{array}{l}\text { FYM } \\
\text { Levels }\end{array}$} & \multirow[b]{2}{*}{$\begin{array}{c}\text { Superphosphate } \\
\text { Levels }\end{array}$} & \multicolumn{4}{|c|}{ Season 2014} & \multicolumn{4}{|c|}{ Season 2015} \\
\hline & & $\begin{array}{c}P \\
\text { concentration } \\
\text { in } \operatorname{shoot}(\mathrm{ppm})\end{array}$ & $\begin{array}{c}\mathbf{P} \\
\text { concentration } \\
\text { in grain(ppm) }\end{array}$ & UP & PUE & $\begin{array}{c}P \\
\text { concentration } \\
\text { in } \operatorname{shoot}(\mathrm{ppm})\end{array}$ & $\begin{array}{c}\mathbf{P} \\
\text { concentration } \\
\text { in grain(ppm) }\end{array}$ & UP & PUE \\
\hline \multirow{3}{*}{ Without } & 100 & 718.1 & 2600 & 9.22 & 33.6 & 850 & 2540 & 11.49 & 74 \\
\hline & 200 & 820.3 & 2802.5 & 8.96 & 17.7 & 852.5 & 2700.7 & 11.91 & 40.2 \\
\hline & 300 & 885.7 & 2280 & 8.88 & 15.3 & 1013.3 & 2237.3 & 12.46 & 29.6 \\
\hline \multirow[t]{3}{*}{ With $3 m^{3}$} & 100 & 1409.4 & 2702.2 & 16.88 & 132.1 & 1322.5 & 2802 & 20.66 & 213.9 \\
\hline & 200 & 813.6 & 3529 & 15.2 & 80.8 & 712.5 & 3629.6 & 18.12 & 89.6 \\
\hline & 300 & 1308 & 2392.5 & 13.78 & 42.9 & 1195 & 2492.5 & 19.77 & 66.8 \\
\hline \multicolumn{2}{|r|}{$\mathrm{LSD}_{0.05}$} & 359.7 & 188.7 & NS & NS & 171.8 & 187.7 & NS & 23.06 \\
\hline
\end{tabular}

\section{References}

Adembaa, J.S., J. K. Kwacha, A. O. Esilabab and S. M. Ngaric. 2015. The Effects of Phosphate Fertilizers and Manure on Corn Yields in South Western Kenya. East Afri. Agric and fores. J. 1: 1-11.

Adeniyan, O. N., A.O. Ojo, Akinbode and J.A. Adediran. 2011. Comparative study of different organic manures and NPK fertilizer for improvement of soil chemical properties and dry matter yield of maize in two different soils. J. Soil Sci. Environ. Manage. 1: 9-13.
Ali, M.E., M.R. Islam and M. Jahiruddin. 2009. Effect of integrated use of organic manures with chemical fertilizers in the rice cropping system and its impact on soil health. Ban. J. Agri. 34:81-90.

Ayuba, S. A., C. John and M.O. Obasi. 2005. Effects of organic manure on soil chemical properties and yield of ginger. Nigerian Journal of Soil Science. 15: 136-138.

Bahl, G.S. and G.S. Toor. 2002. Influence of poultry manure on phosphorus availability and the standard phosphate requirement of 
crop estimated for quantity intensity relationships in different soils. Bioresource technology. 85:317-322.

Belay, A., A.S. Claassens, F.C. Wehner and J.M. De Beer. 2001. Influence of residual manure on selected nutrient elements and microbial composition of soil under long-term crop rotation. South Afr. J. Plant Soil. 18:1-6.

Bello, O.B. A., S.Y. Afolabi and M.S. Ige. 2010. Correlation and path coefficient analysis of yield and agronomic characters among open pollinated maize varieties and their F1 hybrids in a diallel cross. Afri. J. Biotech. 18:2633-2639.

Brady, N.C. and R.R. Weil. 1999. The Nature and Properties of Soils. Twelve Ed. Prentice-Hall International, Inc. Upper Saddle River. NJ. USA.

EL-Ghamry, A. M., E. M. Hadidi and A.I. A. EL-Mashaty. 2004. Influence of farmyard manure, Gypsum and sand on chemical properties of heavy clay soil. Egypt. J. Soil Sci. 3: 355-365.

Fageria, N.K., V.C. Baliger and C.A. Jones. 1997. Growth and mineral nutrition of field crops. 2nd Ed. Marcel Dekker. Inc. NY. USA.

Fan, T. L., X. U. Mg, S.Y. Song, G.Y. Zhoua and L.P. Ding. 2008. Trends in grain yields and soil organic $\mathrm{C}$ in a long-term fertilization experiment in the China Loess Plateau. J. Plant Nutr. Soil Sci. 171:448-457.

Jackson, M. L. 1973. Soil chemical analysis. Prentice-Hall. Inc. Englewood Cliffs. N.J. New Delhi. India.

Kihanda, F.M. 1996. The role of farmyard manure inimproving maize production in the sub-humid Centralhighlands of central Kenya. PhD Thesis. UK.
Mohanty, S., N.K. Paidaray and A.R. Rajan, 2006. Availability and uptake of phosphorus from organic manures in groundnut-corn sequence using radio tracer techniques. Geoderma. 133: 225-230.

Muneshwar, S., M. Singh and B. Kumawat. 2008. Influence of nutrient supply systems on productivity of soybean-wheat and soil fertility of Vertisol of Madhya Pradesh. J. Indian Soc. Soil Sci. 56:436-441.

Negassa, W., H. Gebrekidan and D. K. Friesen. 2005. Integrated Use of Farmyard Manure and NP fertilizers for Corn on Farmers Fields. J. Agrir. 2:131-141.

Nelson, R.E. 1982. Carbonate and gypsum Cited from USDA (1991). Soil

Survey Laboratory Methods Manual. Soil Survey Investigations Report No.42 Version 1: 280-284.

Olsen, S.R., C.V. Cole, F.S. Watanabe and L.A. Dean. 1954. Estimation of available phosphorus in soils by extraction with sodium bicarbonate. U.S. Dept. Agr. Circ. 939.

Randjelovic, V., S. Prodanovic, Z. Tomic and A. Simic. 2011. Genotype $\mathrm{x}$ year effect on grain yield and nutritive values of maize (Zea mays L.). J. Anim. Vet. Sci. Adv. 7:835-840.

Salasya, B.S., W. Mwangi, H. Verkuijl, M.A Odendo and J.O. Odenya. 1998. An assessment of the adoption of grain and fertilizer package and role of credit in smallholder maize production in Kakamega and Vihiga districts. Kenya. Mexico. D. F immyt and Kari.

Sanchez, C.A. 2007. Phosphorus.In: Handbook of Plant Nutrition. Barker and Pilbeam. CRC Press Taylor and Francis Group. Boca Raton. USA. Chapter 3. pp.51-90.

Shaikh, N.F. and B.D. Gachande. 2013. Influence of Organic and Inorganic 
Inputs on Soil Physico-Chemical Properties of Jowar Field. International Journal of Science and Research. 6.14.

Singh, A. K., L.P. Amgain .and S.S Singh. 1998. Integrated nutrient management in Rice wheat system under midland situation In Extended Summaries of 21 st International Congresson Agronomy. held at New Delhi. 450-451.

Singh, C. P.; M. M. Mishra and K.S. Yaday. 1980. Solubilization of inositol $\mathrm{P}$ by thermophilic fungi. Annalsde Microbiologie 131 B: 289-296.

Tadesse, T., N. Dechassa, W. Bayu and S. Gebeyehu. 2013. Effects of Farmyard Manure and Inorganic Fertilizer Application on Soil Physico-Chemical Properties and Nutrient Balance in Rain-Fed Lowland Rice Ecosystem. Ameri- can Journal of plant Sciences. 4: 309-316.

White, R. E. 2006. Principles and practice of soil science. The soil as a natural resource. $4^{\text {th }}$ ed. Blackwell Publishing company. Chapter 10. pp.200-229.

Zhang, W.J., X.U. Mg, B.R. Wang and X.J. Wang. 2009. Soil organic carbon, total nitrogen and grain yields under long-term fertilizations in the upland red soil of Southern China. Nutr. Cycl. Agro.Ecosyst. 84:59-69.

Zhao, Y., P. Wang, J. Li, Y. Chen, X. Ying and S. Liu. 2009. The effect of two organic manures on soil properties and crop yields on a temperate calcareous soil under a wheat-corn cropping system. Eur. J. Agron. 31: 36-42. 
تأثير السماد البلاي ومعدلات التسميد الفوسفاتى على تيسر الفوسفور ومحصول الذرة الثامية

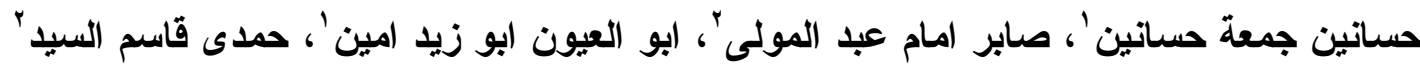

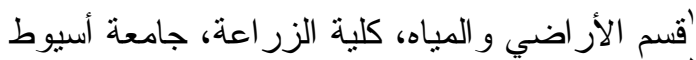
كأقسم الأراضي والمياه، كلية الزر اعة، جامعة الأزهر

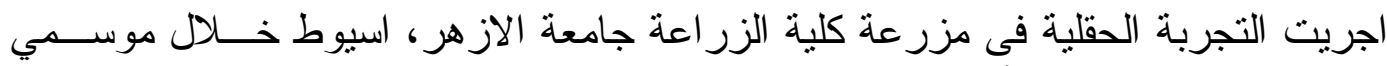

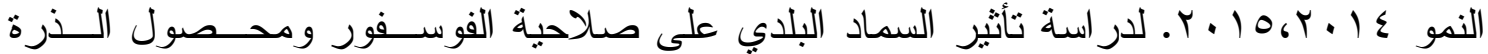

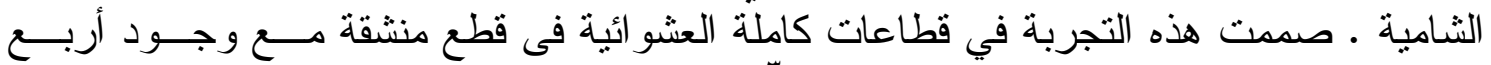

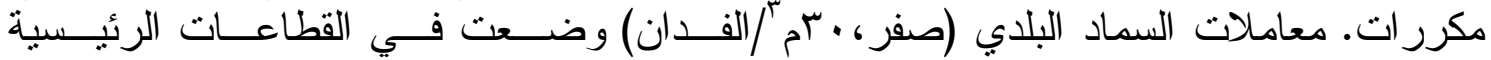

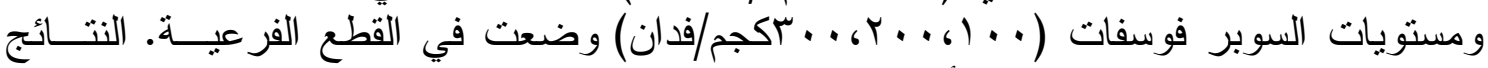

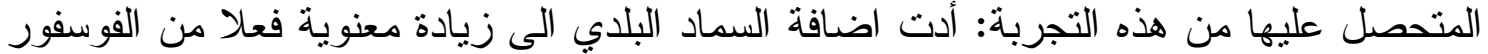

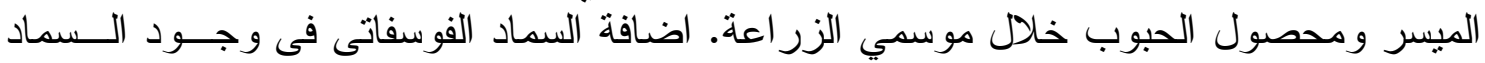

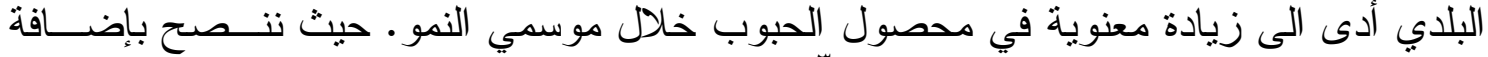

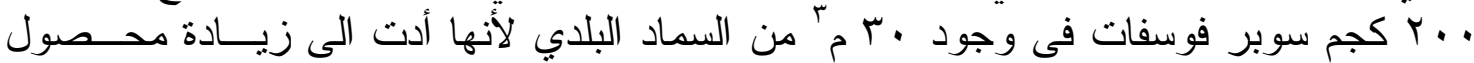

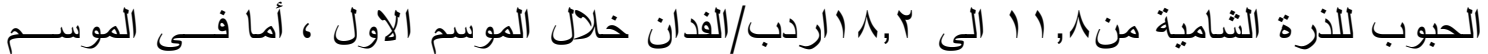

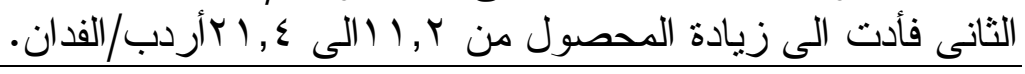

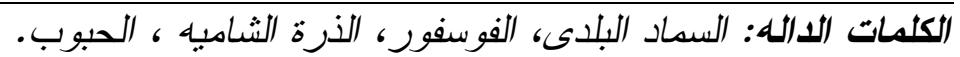

